\title{
BLICKDIAGNOSE
}

Diese Patientin war nie beim Arzt

\section{Was sich unter Taschentüchern verbarg}

Ich wurde bei einem Hausbesuch zu einer 82-jährigen Frau gebeten, die in ihrem bisherigen Leben noch keinen einzigen Arztkontakt zu verzeichnen hatte. Ihre Nichte kündigte mir gegenüber an, ich solle mir "nur mal was anschauen". Bei meinem Besuch fand ich die 82-jährige, etwas wortkarge Frau im Bett liegend vor. Unter der Bettdecke schaute der mit Stofftaschentüchern umwickelte rechte Unterarm hervor. Diesen sollte ich mir also ansehen.

— Die mit im Haushalt lebende Schwägerin machte sich daran, den „verbundenen“ Unterarm auszuwickeln. Unter der Stofftaschentuchschicht war eine Papiertaschentuchschicht, welche nun auch etwas mühsam, weil angeklebt, entfernt wurde. Dabei kam der abgebildete Unterarm zum Vorschein.

Auf meine Nachfrage wurde mir berichtet, dass vor vielen Jahren eine kleine Hautveränderung am Unterarm der Frau aufgetreten sei, welche sich im Laufe der Jahre wie abgebildet entwickelt habe. Zu einem Arztbesuch war die Frau nicht zu bewegen.

Zunächst wurde eine weitere diagnostische Abklärung mit nachfolgender Therapie von der Frau vehement abgelehnt. Nach einiger Überzeugungsarbeit gelang es uns jedoch, sie in eine nahegelegene Universitätsklinik einzuweisen. Die Verordnung von Verbandsmaterial - statt der Taschentücher - wurde mit der Begründung "das haben wir schon immer so gemacht " abgelehnt. Ein gelungener Beitrag zur Kostendämpfung im Gesundheitswesen! Nach Information der Klinik handelt es sich um ein über die Jahre progredientes niedrig malignes Plattenepithel-

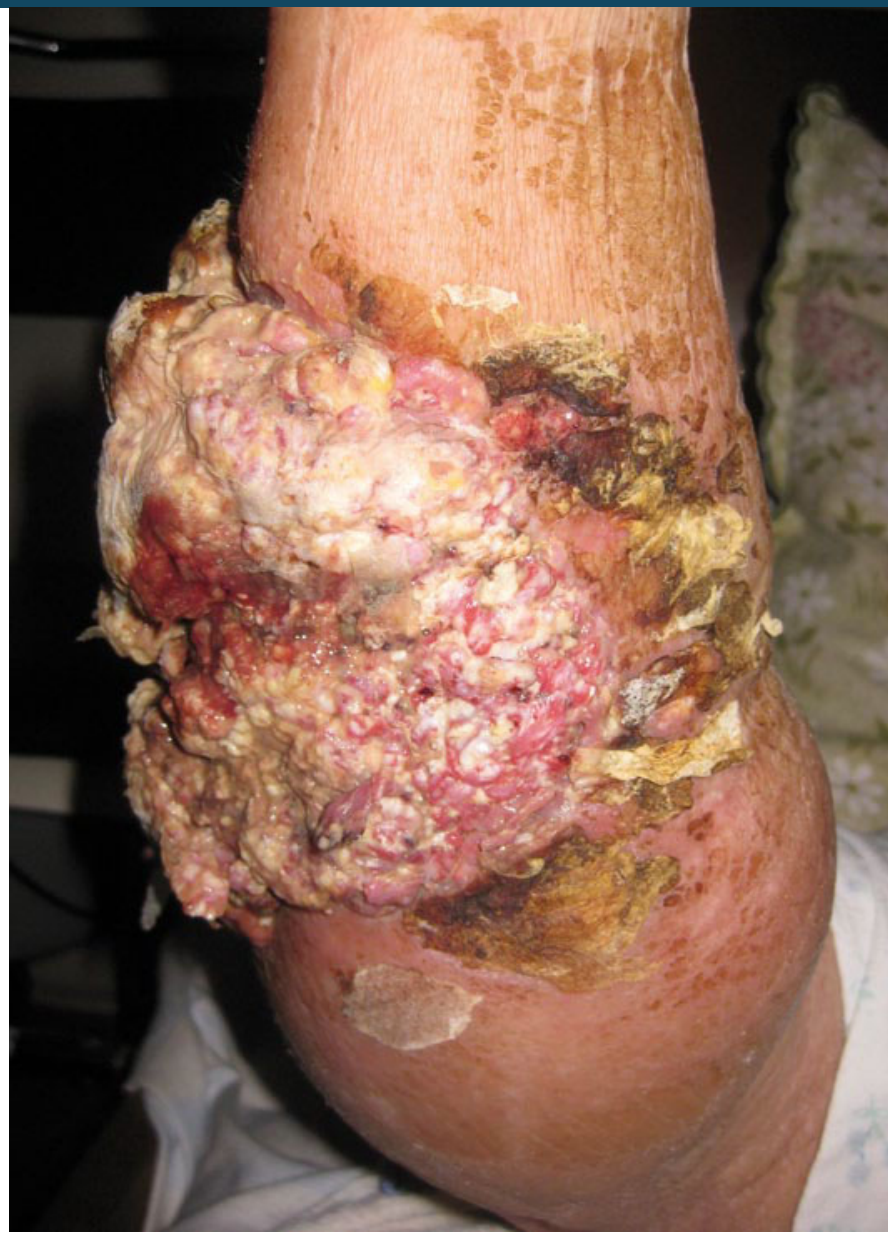

karzinom der Haut. Vorgesehene Therapie: ausgedehnte Haut- und Subkutanresektion, Vakuumversiegelung, nach einiger Zeit Spalthautdeckung.

Keywords: squamous cell carcinoma

- Dr. med. Heinz Ullrich, Zentrum für Allgemeinmedizin, Jakobiweg 9, D-86551 Aichach

www.springermedizin.de

Weitere Blickdiagnosen finden Sie im Internet unter:

http://www.springermedizin.de/blickdiagnose 